\title{
Nutritional intervention for sustainable production in inland saline aquaculture a budding perspective in India
}

\begin{abstract}
Aquaculture is emerging as a new hope to feed the burgeoning population that put thrust on each and every resource to be utilized wisely and sustainably for production of food. Inland saline water aquaculture is one of the important avenue for it. The increasing awareness on nutrition specific to species and culture environment has led a paradigm shift towards culture specific formula to improve environmental adaptation and productivity ensuring long-term sustainability. Generally the poor health, reduced growth rate and frequent mortality are some of the symptom of the inland saline aquaculture. The major cause for it is the deviated ionic composition of the water and lack of the natural food chain, which leads pronounced effect on cultured species. Especially low potassium have been identified as the cause of growth disturbance, as balance between potassium and sodium ions is required for cell volume and hydration. In most of the cases constraint is the alteration of $\mathrm{Na}+$ and $\mathrm{K}+$ ratio in the tissue fluids, which disturb physiological functions of the aquatic animals. The resultant energy demand triggered by $\mathrm{Na}+/ \mathrm{K}+$ ATPase to cope up the osmoregulation and homeostatic maintenance are an additional nutritional burden. This review aims to summarize the role of nutritional augmentation for osmoregulation and amelioration of stressor impact. Additionally cost effective strategy to cope elevated energy and major nutrients requirement for immune augmentation, maintenance of homeostasis and growth with targeted use of dietary additives and balanced nutrients for adaptation of shrimp and fish in inland saline aquaculture.
\end{abstract}

Keywords: Inland saline water, Nutritional, Osmoregulation, Dietary, Adaptation
Volume 6 Issue 5 - 2017

\author{
Md Aklakur Aklakur \\ Fish Nutrition Biochemistry and Physiology Division Central \\ Institute of Fisheries Education India
}

Correspondence: Md Aklakur Fish Nutrition Biochemistry and Physiology Division Central Institute of Fisheries Education India,Tel 9 I 22 263636404, Email aklakur@cife.edu.in

Received: June 07, 2017| Published: December 14, 2017

\section{Introduction}

Optimum utilization of available resources has became a necessary due to increasing population pressure in the developing nations. The burgeoning population put thrust on each and every resource to be utilised wisely and sustainably for production of food specially quality protein to feed the population and eradicate malnutrition. Among such underutilised resources, the saline affected land is about 10.1 million ha in India, which suffer from soil salinity problem. However, during the last decade several agencies have given divergent estimates about Indian inland saline area, as National Commission on Agriculture, 7.16 million ha; National Bureau of Soil Survey and Land Use Planning, 6.2 million ha. The data from various sources were critically evaluated at central soil salinity Research Institute, Karnal and figure has now been modified to 7.4 million ha as depicted by the graph below. Since the use of such land and under lying ground saline water is very restricted, so inland saline aquaculture i. e. culture of aquatic animals and plants using inland (Non-coastal) sources of saline ground water are very promising for its sustainable use. Due to non-utilization of ground saline water, the water table in these areas is rising with an alarming rate causing secondary salinization and water logging conditions leading to fertile productive land being gradually unproductive with poor quality water. Pumping of ground saline water therefore is necessary to lower down the water table to a safer root zone so that surface soil remains un-affected with salinity problem providing good soil conditions for adjacent agriculture crops. Pumping of saline water and its safe disposal in landlocked area is a challenging task and possible only through evapo-transpiration, which is a very costly affair; this could be made economically viable through aquaculture practices in which large proportion of water could be evaporated from aquaculture ponds along with production of high income generating fish/prawn/shrimp crops. However, this is not as simple as in coastal waters, since inland saline water is totally different from fresh, brackish and marine water due to unbalanced ionic composition of inland saline water.

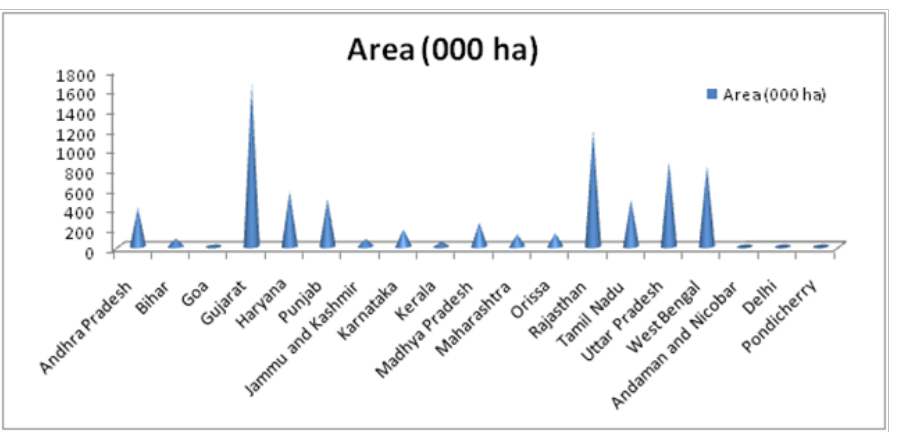

Figure I Status of Saline Soil in India (Source: Central Soil Salinity Research Institute, Karnal, 1996).

\section{Features of saline soil}

Saline soils are those soils which contain salts like chlorides and sulphates of sodium $\left(\mathrm{NaCl}\right.$ and $\left.\mathrm{Na}_{2} \mathrm{SO}_{4}\right)$, calcium $(\mathrm{Ca})$ and Magnesium $(\mathrm{Mg})$. Soil $\mathrm{pH}$ is less than 8.2; Exchangeable sodium percentage (ESP) is less than $15 \mathrm{EC}_{\mathrm{e}}$. Saline soils have high amount of soluble salt, which measured in terms of electrical conductivity of the saturated soils extract, whichare always more than $4 \mathrm{ds} / \mathrm{m}$. Saline soils contain neutral soluble salts, mostly $\mathrm{Cl}^{-}$and $\mathrm{SO}_{4}$ of $\mathrm{Na}^{+}, \mathrm{Ca}^{2+}$ and $\mathrm{Mg}^{2+}$ but $\mathrm{CO}_{3}$ is absent. It contributes permanent hardness to the water. 


\section{Aquaculture as a new perspective for inland saline water (ISW) from a curse to boon}

Several actions have been taken for remediation of the problem, including an attempt to use ISW for marine aquaculture. Later has been seen as a remedial approach to reduce the cost of groundwater pumping and create economic opportunities for the farmers in the affected areas. ${ }^{1}$ To date, studies on the use of inland saline water (ISW) as an alternative source for marine aquaculture have been attempted in countries like the USA and Australia. If the use of ISW as a medium for marine aquaculture can be proven cost effective, then it should be considered as an alternative aquaculture. It has some comparative advantages over the coastal areas in terms of cheap land availability, better quarantine capability and freedom from conflict over the same resources. ${ }^{2}$ Only witnessed constraints and concern is deviated composition of these water and its proper amelioration.

\section{Constraint for the fish culture}

Almost in all ground water composition studies pertaining to inland saline aquaculture, including Australia ${ }^{3-5}$ reflects a clear point that the salinity found is marginal or sub-optimal and their ionic composition (chloride, sulphate, bicarbonate, sodium, magnesium, calcium, potassium) deviates greatly from that of normal seawater. Effects of differences in ionic balances on cultured species are very pronounced. For aquatic organisms, a good balance between potassium and sodium ions is required. As their proper balance regulate the cell volume and hydration. In most of the cases 'low potassium' have been identified as the cause of growth disturbance. In the Australian studies, low potassium concentrations may have negative effects on cultivated organisms at K: Na below $0.01 .^{6}$ Quite similarly, Indian inland saline water had are deficient in $\mathrm{K}^{+}$over $\mathrm{Na}^{+}$.

Another constraint is the water hardness by chloride and sulphate which may influence the uptake chemistry of ions by the organisms. In most groundwater types examined, $\mathrm{Ca}$ : $\mathrm{Mg}$ rations also deviated from those in seas and oceans (normally - 0.2); in groundwater it increased to 0.5 . The water hardness index $(\mathrm{Ca}+\mathrm{Mg})$ : $(\mathrm{Na}+\mathrm{K})$. The hardness index of 'normal seawater' is around 0.13 , whereas in most of groundwater types it is usually between 0.25 and 0.30 . To diagnose any physiological effect on organisms, possibly due to ion imbalances, a signature plot of relevant ratios: $\mathrm{SO}_{4}: \mathrm{Cl}, \mathrm{K}: \mathrm{Na}, \mathrm{Ca}: \mathrm{Mg}$, $(\mathrm{Ca}+\mathrm{Mg}):(\mathrm{Na}+\mathrm{K})$, are essential marker parameter. These parameter along with physiological effect will lead to the way for adaptation mechanism in ISW culture.

Alike to ocean water, sodium and chloride are the determinant the salinity of the ISW ${ }^{7}$ and the osmolality of the haemolymph of the cultured species is regulated by set of ions beside these ions. ${ }^{8}$ Low $\mathrm{K}^{+}$concentration in ISW occurs due to adsorption of the $\mathrm{K}^{+}$on to the clay. ${ }^{2}$ Although, $\mathrm{K}^{+}$concentration only contribute a small part of the total ions making up the ISW, it plays an important role in the functioning of the physiological systems of the aquatic animals. ${ }^{9}$ In aquatic life, $\mathrm{K}^{+}$is very important to activate $\mathrm{Na}+\mathrm{K}+$ ATPase,${ }^{10}$ which is responsible for maintaining the ionic imbalance in the haemolymph. Therefore, alteration of $\mathrm{Na}+$ and $\mathrm{K}+$ ratio in the haemolymph may disturb entire physiological functions of the aquatic animals. The resultant energy demand triggered by $\mathrm{Na}+/ \mathrm{K}+$ ATPase to cope up the osmoregulation is an additional nutritional burden on the animal and accordingly dietary and homeostatic maintenance become essential. The use of ISW as a medium for culture of marine fish and prawns can only be successful if the mineral $\left(\mathrm{K}^{+}, \mathrm{Mg}^{++}\right)$deficiency in ISW can bee laminated, e.g. by fortifying the $\mathrm{K}^{+}$concentration in ISW and dietary supplementation of minerals. In addition to it the elevated energy budget and nutritional requirement has to be fulfilled for sustained growth as it is evident in such culture system.

\section{Selection of species - A bidirectional approach to explore the resource}

There are several species of brackish water fish and prawn, beside commercially important freshwater fish and prawn, which can be cultured in ISW, on the basis of their salinity tolerance capacity and commercial importance. The salinity of the ISW ranges from $10-35 \mathrm{ppt}$ with high $\mathrm{Ca}^{2+}$ and $\mathrm{Mg}^{2+}$, which results in high water hardness. ${ }^{11}$ For such water, in experimental farming, culture of Chanoschanos (milkfish), Mugilcephalus (grey mullet), Latescalcarifer (seabass), Etroplussuratensis (pearl spot), Peneausmonodon (tiger prawn) and Litopenaeus vannamei (pacific white) have been done. The suitability of inland saline water for larvae farming and grow out of giant freshwater prawn Macrobrachiumrosenbergii has also been ascertained. Similarly, at low salinity ( $<6 \mathrm{ppt}$ ) culture of Pangasius hypophthalmus and some minor carps like Amur carp, common carp, mystussps have been tried on experimental basis. Rahman et al. ${ }^{12}$ reported that black tiger prawns can experience high mortality when cultured in ISW, but survival and growth rates can be improved if the ISW is fortified with $\mathrm{K}^{+}, \mathrm{Mg}^{2+}$ and $\mathrm{Ca}^{2+}$. Grey mullet and milkfish ${ }^{11,13}$ can survive and grow well in ISW ponds. Similarly, Jain et al. ${ }^{13}$ reported that barramundi can survive and grow at lower salinity.

Probably the best candidate for inland saline water culture is penaeid prawns, although P.monodon performed poorly in preliminary trials conducted in Victoria (pers. comm. Brett Ingrarn). Ruello ${ }^{14}$ reports that $P$. Vannamei has been successfully cultured ISW and that three penaeids (F.indicus, Metapenaeusmonoceros and M. merguensis) have potential to grow faster in inland saline. For culture of these shrimp, mineral supplements, in the form of fertilizers rich in $\mathrm{K}^{+}$and $\mathrm{Mg}^{2+}$, have been suggested as remedial methods to get growth and survival of shrimp cultured in low salinity waters. Saline ground waters have another potential advantage of culture of algae for food and feed, brine shrimp Artemia is in high demand as a feed source for fish culture, especially for ornamental fish and demand is significantly greater than the availability. Fish with future potential for inland aquaculture in the longer term (as reliable culture methods are to be developed) include mangrove jack (Lutjanusargentimaculatus), cod (Epinephelussps), cobia (Rachycentroncanadum), Silver Pompano (Trachinotusblochii) and various other marine and estuarine species.

\section{Physiological stress and adaptation}

Osmoregulation, somatic growth, and reproduction are among the most energy demanding metabolic activities engaged by aquatic organism including fish and shellfishes. Boeuf and Payan ${ }^{15}$ discussed four possible pathways of interaction between osmoregulation and growth:

i. Difference in standard metabolic rate,

ii. Increase in food intake,

iii. Alteration in digestibility, and

\section{iv. Hormonal stimulation.}

The interaction of these can be considered as a unique route connecting osmoregulation and growth. When confronted with salinity stress, aquatic animals are forced to adapt to the changing environment 
through osmo regulation via the change of various enzymes and transporters, but the physiological adaptations to these functional changes are highly energy demanding. ${ }^{16}$ Therefore, the provision of sufficient nutrients and energy through dietary manipulation for these culture species in ISW is necessary to enhance the ability for fish and shrimp to cope with low-salinity environments. Salinity represents a critical environmental factor for all aquatic organisms, including fishes, mollusc and crustaceans. Environments of variable salinity are inhabited by euryhaline fishes having wide salinity tolerance ranges. Euryhaline fishes harbour mechanisms that control dynamic changes in osmoregulatory strategy from active salt absorption to salt secretion and from water excretion to water retention. These euryhaline fishes are having actual potential for culture in ISW. The mechanisms of dynamic control of osmoregulatory strategy include the ability to perceive changes in environmental salinity that perturb body water and salt homeostasis (osmo-sensing), signalling networks that encode information about the direction and magnitude of salinity change, and epithelial transport and permeability effectors. Generally proteins are involved in combinatorial osmo-sensing and are likely to be interchangeable. Most of euryhaline fishes have an upper salinity tolerance limit of approximately double to the normal seawater.

If we considered concurrently the most preferred cultured species of shrimp (L.vannamei) in Inland saline water, is definitely a stressful culture. Therefore, extra mineral and energy must be supplied to achieve optimal growth and survival of $L$. vannamei at low salinity in ISW. Oxygen consumption has been considered a good indicator for assessing the energy utilization under different salinities in $L$. vannamei, as reported in other decapod crustacean species. The $L$. vannamei at low salinity usually show poor growth performance, but findings on the impact of salinity on the growth of shrimp are not consistent. But grows particularly well at low salinities of around 10$15 \mathrm{ppt}$ (where the environment and the blood are isosmotic). ${ }^{17}$ This ability makes it a good candidate for the newer inland saline farms that have become common in inland saline soil areas. For example, a high percentage of Chinese $P$. vannamei are cultured in inland, freshwater sites, where production is much higher than with the indigenous species.

In physiological adaptation to ISW, two main physiological features of osmoregulation, active ion transport through the $\mathrm{Na}+/$ $\mathrm{K}+$-ATPase pump and fatty acid composition of membranes affecting permeability to water and ions, cannot fully explain differential survival to an salinity stress. This observation is derived from different experimental finding, which suggested nutritional status and normal genetic variation as growth and survival drivers. Most crustacean species living in seawater are osmo conformers, while those that live in freshwater are hyperosmotic osmoregulators. Hyperosmotic regulators have an osmolality that is higher than their environment, facing hydration and diffusive loss of ions and requiring energy consumption for osmotic regulation. ${ }^{8}$ This kind of adaptation is followed by freshwater fish cultured at low salinity in saline soil areas. But at high salinity the body osmotic pressure is less than that of environment and osmoregulation is ensured by increasing solutes concentration in body fluid temporarily by potassium ions and permanently of free amino acids, amines and other solute in combination to minerals. Especially in crustaceans salt movement occurs at the level of permeable surfaces, such as the body wall, gastrointestinal tract, excretory organs, and gills. ${ }^{18}$ Gills, specialized in osmoregulation, have specialized cells for active ion transport. It suggests the active energy demand for such transport and osmoregulation.
The membrane permeability regulates the movement of salt and cell volume, finally function of the cell. Permeability in crustacean is highly variable and excretory organs, particularly the antennal gland, regulate the volume of body fluids, the concentration of some organic solutes. The gills of osmoregulating aquatic organism have a primary osmoregulatory function compared to kidney or excretory organ and former function mostly for respiration ${ }^{19}$ and the highest ATPase specific activity is found in the gills of aquatic organism. In shrimp, the functional activation of $\mathrm{Na}+/ \mathrm{K}+$-ATPase at salinity stress is not, ${ }^{20}$ indicating that active ion transport per se, so the same is enough to explain natural (genetic) variability of survival to salinity stress. Another characteristic, which is related to active ion transport is the anatomical basis of a larger gill area, which apparently is associated with survival to salinity stress tests (SST) in several experimental models, particularly to explain individual variation and influence of HUFA. Feeding a rich HUFA diet have larger gill area ${ }^{21,22}$ which agrees with the observation of a more ramified gill structure in HUFAfed PL. ${ }^{23}$ In addition to the above osmoregulatory mechanisms, a larger gill area has an increased ion transport surface and possibly the number of cells that contain $\mathrm{Na}+/ \mathrm{K}+$-ATPase pumps available to exchange ions.

Furthermore, the gene expression level study also reflects the altered gene expression. The suppression subtractive hybridization has been used to investigate the effect of long-term salinity stress between $2 \mathrm{ppt}$ and $30 \mathrm{ppt}$ on the gene expression in the hepatopancreas of juvenile $L$. vanname $i^{24}$ and the study revealed that eleven genes encoding immunerelated proteins and enzymes, including haemocyanin, ecdysteroidregulated protein, $\mathrm{C}$-type lectin1, cathepsin $\mathrm{L}$, chitinase, cathepsin $\mathrm{C}$, zinc proteinase mpc 1 , trypsin, trypsin gene 2 , chymotrypsin 1 and lysozyme got altered. Furthermore, the superoxide dismutase and catalase activities in the muscle and hepatopancreas at $3 \mathrm{ppt}$ were higher than those at $17 \mathrm{ppt}$, indicating that low salinity can stimulate the production of free radicals for scavenging, and the increased activity of superoxide dismutase and catalase can enhance the ability to scavenge radicals and maintain the health of L. vannamei. ${ }^{25}$ These observation clearly necessitate nutritional and nutraceutical intervention in the salinity adaptation in inland saline culture of fish and shellfishes. The nutraceuticals for protection against oxidative stress, metabolic and immune suppression are key along with dietary support for coping elevated energy and nutritional requirement.

\section{Nutritional intervention for sustainable production}

The culture of marine species in inland areas has great potential, as it could diversify aquaculture, provide alternative species for existing aquaculture operations. However, because the animals are maintained in aberrant environment, a variety of unique problems come and all these problems are pertaining to deviated ionic composition of such water, temperature and food web. For shrimp, the problems unique to low-salinity inland systems include highly variable survival rates between ponds; mortality when the animals are subjected to salinities and/or temperatures changes within their range of tolerance, tail cramping, lethargy, disoriented spinning behaviour, slow growth, improper coloration in the shrimp. Most of these problems are related to physiological and dietary imbalances associated with the unique rearing environment. As in the normal marine environment the physiological adaptation and dietary intake tune with environment and it has evolved in long run with natural food web.

Taking marine organisms from waters of high salinity to low salinity causes two major physiological stresses: the diffusive loss of salts from the haemolymph or blood to the medium and resultant 
uptake of water from the medium. The second stress can be particularly damaging. Tissues and cells take up water and increase in volume, and the resulting cell swelling impairs normal functions. To cope these changes, aquatic animal goes to change the membrane permeability, try to adjust the ionic $\left(\mathrm{Na}^{+}, \mathrm{K}^{+}\right.$,) and solute concentration of tissue fluid to maintain normal osmotic concentration. In general, marine shrimp species reared in seawater do not require dietary sources of magnesium and potassium, which are high in natural seawater, whereas freshwater species reared in freshwater require dietary supplements. Shrimps require a dietary source of potassium when reared in brackish water, but may not when reared in full-strength seawater.

Dietary supplementation of ingredients that might improve the osmoregulatory capacity of shrimp have also been examined by a number of researchers as a potential means of improving growth and survival in low salinity waters. Fertilizers utilized by farmers to supplement $\mathrm{K}$ and $\mathrm{Mg}$ to pond water can to be costly as soil has very high affinity for adsorbing it. Depending on the ion profile and size of each pond as well as the number of ponds on a given farm, fertilization to correct ionic deficiencies can be a large financial cost for some inland commercial shrimp operations. Inclusion of dietary supplements such as $\mathrm{K}$ and $\mathrm{Mg}$ in the feed, if successful, could provide a considerable cost-savings for inland shrimp operations beside conventional fertilization approach or in combination. There has been several attempt to delineate the efficiency to dietary supplementation as an approach to improve the growth and survival of shrimp in the inland saline areas (Table 1). But most of the work has been done in shrimp as the high value entity, as it give scope for supplementation.

Table I Studies evaluating different dietary supplements to improve growth and survival of shrimp reared in low salinity waters (Adapted from Roy \& Davis $^{43}$ )

\begin{tabular}{ll}
\hline Supplement & Reference \\
\hline Potassium & Gong, Roy, Saoud, et al..$^{54,57,67}$ \\
Magnesium & Gong, Cheng, Roy, et al. ${ }^{54,88,97,98}$ \\
Sodium Chloride & Gong, Roy et al. ${ }^{54,57}$ \\
Betaine & Saoud \& Davis \\
Arginine & Saoud et al. ${ }^{43}$ \\
Threonine & Huai et al. ${ }^{90}$ \\
Cholesterol & Gong, Roy et al. ${ }^{54,96}$ \\
Lecithin & Roy et al. ${ }^{96}$ \\
HUFAs & Palacios, González-Félix et al..$^{21,89}$ \\
Carbohydrates & Wang et al. ${ }^{33}$ \\
Astaxanthin & Flores et al. ${ }^{79}$ \\
Prebiotics & Li et al. ${ }^{76}$ \\
Glycine & Xie et al. ${ }^{83}$ \\
Leucine & Liu et al. ${ }^{95}$ \\
Biotin & Xia et al. ${ }^{100}$ \\
Niacin & Xia et al. ${ }^{101}$ \\
Vitamin E & Liu et al. ${ }^{72}$
\end{tabular}

Another approach being followed for the euryhaline aquatic organism is exploring its best stage to adapt such environment. Osmoregulation is energetically very costly and necessary in species like penaeid shrimp. Larvae development occurs in the ocean while post larvae are recruited into coastal zones (estuaries and lagoons) where they growth up to juveniles and adults. ${ }^{26}$ Just before recruitment, individuals should have developed their physiological capabilities to overcome the fluctuating nature of those environments. ${ }^{27}$ It has been evaluated only in the tiger shrimp P.japonicus ${ }^{28}$ and more recently in the blue shrimp Litopenaeusstylirostris. ${ }^{28}$ The recent attention has been paid on the effect of salinity (including low and high salinity) on survival one of the most important penaeid species, Litopenaeusvannamei. While other approach of the mineral addition in water and dietary supplementation of minerals nutrients and nutraceuticals are the key approach followed on farm. Similarly in fishes, saltwater survival of $O$. mossambicus improved by $84 \%$ after two weeks of feeding the salt diet, and that of the $O$. aureus x $O$. niloticus hybrids by $62 \% .{ }^{29}$ In all-male tilapia hybrids (O. aureus X $O$. niloticus) fed with feed that did not contain fish meal, $3 \%$ dietary salt supplementation resulted in about $20 \%$ improvement in specific growth rate and feed conversion ratio while cultured in freshwater for two months. ${ }^{30}$ It reflects acquired adaptation of fish to the aberrant salinity by nutritional supplementation.

\section{Nutrients and its significance for salinity adaptation in inland saline aquaculture}

The relation between particular biochemical reserves that can be used directly for osmoregulation or to withstand general salinity stress is supported by higher levels of glucose and acylglycerides, compared to same-age batches cultured under the normal conditions..$^{31,20,32}$ Chausson \& Regnault ${ }^{32}$ found more carbohydrate reserves in posterior than in anterior gills. These reserves can be used as an energy pool for the $\mathrm{Na}+/ \mathrm{K}+$-ATPase pump. The role of carbohydrate as a source of energy for osmoregulation is illustrated by higher dietary carbohydrate requirements for shrimp exposed to decreasing salinities..$^{33}$ During short-term starvation, carbohydrates are usually the first macronutrients to be depleted, thereafter, lipids and proteins are used. A reversible increase in free amino acids is a welldescribed mechanism to maintain osmotic balance between intra and extracellular compartments in seawater. ${ }^{34}$ But when salinity decreases, the free amino acids might be oxidized with concomitant excretion of $\mathrm{NH} 4^{+35}$ or incorporated into proteins. In turn, the excretion of $\mathrm{NH}^{+}$in diluted media can be coupled to $\mathrm{K}^{+}$uptake in gills. ${ }^{36} \mathrm{~A}$ mobilization of lipids to gills from the hepatopancreas was suggested in PL submitted to a salinity challenge. ${ }^{37}$ Lipids in gills decreased in crabs acclimated to diluted sea water during $72 \mathrm{~h} .{ }^{38}$ Kinsey et al..$^{39}$ concluded that for crabs exposed to hypoosmotic conditions for 7 days both gill types oxidized glucose and amino acids, while posterior gills preferentially used fatty acids as metabolic fuels for active ion pumping. A decrease in saturated and monounsaturated fatty acids in neutral lipids of gills after exposure to $10 \mathrm{ppt}$ for $3 \mathrm{~h}$ can be a result of energy production for osmoregulation by selective fatty acid oxidation..$^{40}$ Therefore the each major nutrient has its own significance in response to low salinity / deviated salinity adaptation in inland saline aquaculture.

\section{Protein}

The relationship between protein requirements and water salinity extremes especially in shrimp is very pronounced. For example, in high saline conditions, L. Vannamei respond positively to increased dietary protein, while the protein requirements for P.monodon have been reported higher when they are reared in low-salinity water. However, the effects of dietary protein levels on growth performance and immune condition of juvenile $L$. vannamei at $1 \mathrm{ppt}$, showed that the feed intake, specific growth rate, feed efficiency ratio improved with the increase in dietary protein from $20 \%$ to $40 \%$, and a reduction in total hemocyte count, haemolymph protein and haemocyanin content, phenoloxidase activity and survival in the salinity challenge test was only found in the lowest dietary protein group (20\%). And so, Liu et al. ${ }^{41}$ recommended that $40 \%$ dietary protein can be used in shrimp culture at low salinity to improve growth and health. However, it is practically found that commercial feed with high salinity perform better at high salinity in both $P$ monodon and $L$ vannamei. Similarly, $\mathrm{Li}$ et $\mathrm{al} .{ }^{42}$ found that the growth and condition factor increased by 
increasing the level of dietary protein, but the low survival at low salinity was not improved.

Another index monitored at salinity extreme is free amino acid content of haemolymph free amino acids such as proline, glycine, and alanine are involved in the intracellular osmotic regulation of penaeid shrimp in high salinities. However, in low-salinity waters, these free amino acids are not needed for osmotic balance but may be used for energy to maintain osmotic homeostasis. Therefore, an excess of protein or free amino acids such as arginine, which is phosphorylated as a high-energy derivative controlling the cell content of adenosine triphosphate (ATP), may facilitate the adaptation to low-salinity environments. Although fish and shrimp are more efficient at digesting proteins than carbohydrates and they do obtain a considerable proportion of their energy needs from amino acids pool and dietary protein.

Due to the role that free amino acids play in shrimp osmoregulation ${ }^{43}$ and dietary protein is preferred energy source in fish and shellfishes, dietary supplementation of protein and amino acids has been suggested to improve osmoregulatory capacity of shrimp reared in low salinity. But in controlled experiment the dietary supplementation of free individual amino acids has not shown promising result on growth and survival. Further studies are needed to investigate whether amino acids in combination might be beneficial to aquatic organism cultured in ISW, particularly in the post-larval stages when shrimp are initially stocked into production ponds.

\section{Lipids}

Lipid level in diet and nature of dietary lipid has strong bearing on the salinity stress tolerance and so in the response to inland saline water adaptation. A selective fatty acid oxidation has been observed in gill in PL fed a diet rich in saturated fatty acids. In general, higher HUFA levels in the diet are considered better. However, results have not always been convincing. Similarly result of other lipids, such as phosphatidyl choline (PC) or cholesterol also shows a mixed response. HUFA and other lipids can affect overall physiological condition as a result of enhanced nutritional status or directly affect osmoregulatory mechanisms. Fatty acid composition of membrane phospholipids in gills can be changed in shrimp fed different levels of HUFA. ${ }^{40}$ As fatty acids of membrane phospholipids can influence water and ions permeability and the activity of the $\mathrm{Na}+\mathrm{K}+$-ATPase pump. ${ }^{44}$

Membrane bilayers are composed of phospholipids that have an asymmetric arrangement in the membranes, with the outside composed mainly of PC, whereas phosphatidylserine (PS) and phosphatidyl ethanolamine (PE) are largely confined to the interior membrane. ${ }^{45} \mathrm{PE}$ has a higher gel/ fluid transition temperature than, for example, PC of similar fatty acid chain composition, due in part, to hydrogen bonding between the head groups of PE (but not PC), the close packing permitted by the reduced steric bulk of PE, and the greater hydration of $\mathrm{PC}$ relative to PE. ${ }^{46} \mathrm{PS}$ is acidic and $\mathrm{Na}^{+} / \mathrm{K}^{+}$ATPase selects acidic phospholipids in membranes for interaction. ${ }^{47}$ The level of phospholipids in the posterior gills differs from that in anterior gills in crabs. Euryhaline crabs increase the synthesis of phospholipids in posterior gills in response to changes in salinity, ${ }^{48} \mathrm{PS}$ and PE particularly act as specific carriers of $\mathrm{Na}^{45}$

Distribution of different phospholipids in the membranes could be associated with the location of $\mathrm{Na}^{+} / \mathrm{K}^{+}$ATPase pumps ${ }^{45}$ and activity of the $\mathrm{Na}^{+} / \mathrm{K}^{+}$ATPase, which is dependent on the presence of PS in the cellular membrane in the posterior gills of crabs. In addition to the effect of phospholipids on $\mathrm{Na}^{+} / \mathrm{K}^{+}$ATPase, different fatty acids can be selectively incorporated into each phospholipids class of the cellular membrane. The selective preferences of different phospholipid and their relative proportion can be an interesting area for exploring the adaptive cues in inland saline water. From this very knowledge, it may be speculated that PL exposed to low salinities have to increase their $\mathrm{Na}^{+} / \mathrm{K}^{+}$ATPase activity to compensate for $\mathrm{Na}+$ loss by increasing the levels of PE and PS, and increasing HUFA proportion in these and possibly other phospholipids.

In addition to fatty acids, membrane permeability can be regulated by other lipids, such as cholesterol beside phospholipids. ${ }^{46}$ Although cholesterol in low quantities is essential for shrimp, it is seldom considered as a modulator of osmoregulation in crustaceans. However, cholesterol inhibits water and $\mathrm{Na}^{+}$permeability through phospholipid bilayers, both by restraining the motion of lipid chains and increasing the phospholipids head group spinning motion, thus saving ATP and energy. ${ }^{49}$ Accordingly, increased salinity tolerance has been observed in P. monodon PL fed the highest proportion of cholesterol (1\%) in comparison to diets with lower cholesterol levels. ${ }^{50}$ Phospholipids and cholesterol are essential for normal growth of crustaceans. Dietary deficiencies in cholesterol have been linked to mortality in crustaceans. ${ }^{51}$

Cholesterol plays a role as a necessary precursor for steroid and molting hormones ${ }^{52}$ and phospholipids are involved in gill membrane function, lipid metabolism, and in the incorporation of cholesterol into hemolymph proteins..$^{51,53}$ Due to their role in lipid mobilization and storage, supplementation in excess of the dietary requirement has been suggested as a potential strategy to increase growth and survival of shrimp in LSW. ${ }^{54}$ So the same strategy may play a significant role in inland saline water as well and seem a matter of investigation in species specific manner. Palacios et al..$^{55}$ observed increased survival of post-larvae that were fed diets supplemented with EPA and DHA following a stress test. While the strategy appears to be promising, further studies are necessary, particularly on-farm studies conducted in ISW that track the growth and survival of shrimp offered diets supplemented with high levels of HUFAs, cholesterol and phospholipids over entire production periods.

\section{Carbohydrates}

In spite of the fact that the aquatic organism like fish and shellfishes preferably use protein as energy source, they fulfil their considerable proportion of their energy needs from carbohydrates. Even such energy is essential for the maintenance of ionic pumps for ion exchange and other energy costs associated with osmoregulation. Carbohydrates can play a direct or indirect role in providing energy for osmoregulation. Blood glucose levels fall when shrimp are exposed to extreme salinities, confirming the animal's use of carbohydrates in osmotic adaptation. Hence, there may be advantages to looking at available energy sources which best provide energy for stressful culture conditions in ISW.

With other dietary supplements tested to improve the growth of L. Vannamei reared in LSW the dietary carbohydrates has been given equal importance. Higher dietary carbohydrates have been suggested as a means for shrimp to offset the higher energetic cost of osmoregulation in LSW and for sparing protein. Wang et al. ${ }^{33}$ evaluated the effect of dietary carbohydrate at a range of low salinities and found that specific growth rate of shrimp was higher at low salinity in the shrimp offered diets containing higher carbohydrate levels. Similarly at higher salinity carbohydrate has been found to give better result and reduced FCR at farms. In a study to determine the effects of salinities $(0,1,2,4,8$ or $16 \mathrm{ppt})$ and dietary carbohydrate levels 
$(15.47 \%, 29.15 \%$ or $41.00 \%)$ on survival, growth, food consumption, food efficiency, absorption efficiency and energy budget of juvenile $L$. vannamei, Wang et al. ${ }^{34}$ found that the carbohydrate was an important source of energy for L. Vannamei juveniles at low salinities, and an adequate level of carbohydrate in diets could significantly improve growth performance and also spare the dietary protein for energy supply. Similarly, Wang et al. ${ }^{56}$ evaluated the effects of dietary carbohydrate $(\mathrm{CBH})$ levels on growth, body composition and ammonia tolerance of juvenile $L$. vannamei at a low salinity (3 ppt). A dietary $\mathrm{CBH}$ level of $20 \%$ alleviated the adverse effect of ammonia stress at low salinity. ${ }^{56}$ These observations emphasises the optimisation of dietary carbohydrates at low salinity in ISW, with full possibilities to fulfil the elevated energy requirement due to osmoregulation in cheaper way. Therefore, higher dietary carbohydrate is needed to satisfy the extra energy demand for the optimal growth for juvenile L. Vannamei in LSW (3 ppt) and so for ISW. ${ }^{56}$ Therefore, the around $25-40 \% \mathrm{CBH}$ in the diet is recommended to improve growth performance of shrimp in inland low-salinity ponds by providing direct extra energy for growth and osmoregulation.

\section{Minerals}

Impact of the dietary mineral supplementation in low salinity and inland saline culture has apparently been much emphasized but the species specific variation for utilization of dietary mineral is very much. Research with red drums, Sciaenopsocellatus and Asian sea bass, Latescalcarifer, have indicated positive benefits from addition of salt to diets, when the fish are reared at low salinities. Mostly, the supplementation of potassium, magnesium and sodium chloride to practical diets is recommended and research into the influence of minerals on growth and survival in low-salinity water is warranted. Preliminary trials by the authors adding sodium chloride supplements to shrimp diets have not resulted in enhanced performance. However, delivery of these and other water-soluble salts is technically more difficult in shrimp than fish due to shrimp's feeding habits. In shrimp feeds, the leaching of these minerals is the major problems and it must be addressed to ensure delivery after the pellets are immersed in water. Leaching losses can be reduced by using a variety of techniques to stabilize the pellets or less-soluble chelated or coated forms of the minerals. Another concern is the ability of the minerals to be absorbed in the gut. All these concerns have been found to be crucial in the shrimp culture at low salinity.

Initial efforts to study the cause of high mortality and poor growth of post-larval and juvenile shrimp in low salinity and inland saline water, revealed deficiencies in potassium $(\mathrm{K})$ and magnesium $(\mathrm{Mg})$ in inland LSW utilized for shrimp culture. ${ }^{57}$ Generally variations in pond $\mathrm{K}$ and $\mathrm{Mg}$ levels have resulted in large variations in survival and growth in shrimp raised in different ponds on the same farm. ${ }^{58}$ Deficiencies in $\mathrm{K}$ and $\mathrm{Mg}$ were corrected by pond supplementation of fertilizers containing sources of $\mathrm{K}$ and $\mathrm{Mg}$, including muriate of potash (potassium chloride; 50\% K) and K-Mag ${ }^{\circledR}$ (potassium magnesium sulfate, $17.8 \% \mathrm{~K}$ and $10.5 \% \mathrm{Mg}$ ). The ambiguity of application of fertilizers, in such ponds is that the levels of $\mathrm{K}$ and $\mathrm{Mg}$ are lost due to soil uptake, seepage, or overflow. ${ }^{59}$ Throughout the production cycle, large amounts of $\mathrm{K}$ and $\mathrm{Mg}$ are lost to soil adsorption. ${ }^{18}$

Fortification of water with $\mathrm{K}$ has also been advantageous with a number of other species of shrimp and fish cultured in low salinity environments. ${ }^{6}$ Several studies have focused on the importance of $\mathrm{Na}: \mathrm{K}$ ratios on survival and growth of $L$. Vannamei in LSW. In full strength seawater, the $\mathrm{Na}: \mathrm{K}$ ratio is approximately $28: 1$. In $\mathrm{K}$ deficient waters, such as those used by farmers to grow shrimp in west Alabama, lowering the $\mathrm{Na}: \mathrm{K}$ ratio (by increasing water $\mathrm{K}$ concentrations by the addition of fertilizers) dramatically increases growth and survival of shrimp reared in LSW. Zhu et al. ${ }^{60,61}$ reported that high Na:K levels can have an effect on shrimp growth even at salinities as high as 30 ppt. Roy \& Davis ${ }^{18}$ reports that in west Alabama, they recommend to their farmers lower their $\mathrm{Na}: \mathrm{K}$ ratios to a minimum of $40: 1$, but preferably the ratio should be closer to $28: 1$.

Two main physiological features of osmoregulation, namely active ion transport through the $\mathrm{Na}^{+} / \mathrm{K}^{+}$-ATPase pump and fatty acid composition of membranes, which can affect permeability to water and ions, cannot fully explain the variation in survival under diverse experimental models. Other osmoregulatory mechanisms must be more thoroughly studied to evaluate their role in PL survival. Salinity is often determined as the sum of all ions, particularly $\mathrm{Na}^{+}$and $\mathrm{Cl}^{-}$in the water, but each ion can be regulated differently. ${ }^{35}$ Ionic composition in tap water might vary substantially from one location to another, and this can affect transport proteins, used by PL. On the other hand, PL exposed to deionized water might not be able to osmoregulate adequately because of lack of external ions, and thus survival in these conditions might result from a generally lower permeability.

In addition to age differences of PL, survival to the salinity stress can also be affected by the stage of molt in PL of the same age and batch. Osmoregulation capacity decreases in late pre-molt and early postmolt, ${ }^{62}$ while water permeability increases in crabs during molting. ${ }^{63}$ The activity of the $\mathrm{Na}^{+} / \mathrm{K}^{+}$-ATPase increases in gills and hypodermis of crabs during late pre-molt and early post-molt stages, suggesting that this enzyme plays an important role and adequate dietary minerals are necessary for normal growth and survival of shrimp. ${ }^{64}$ Minerals that play a role in the osmoregulatory process, such as $\mathrm{K}, \mathrm{Mg}$, sodium $(\mathrm{Na})$ and chloride $(\mathrm{Cl})$ have been suggested as dietary supplements for $L$. Vannamei reared in LSW. The basic premise behind this strategy is that a lack of minerals, such as $\mathrm{K}$, in the water column for absorption at the gill might be offset by increased availability, and thus absorption in the digestive tract of the shrimp. This strategy has also been employed in juvenile red drum (Sciaenopsocellatus). ${ }^{65}$ Gong et al. ${ }^{54}$ reported a benefit of a diet supplemented with $\mathrm{K}, \mathrm{Mg}, \mathrm{Na}$, cholesterol, and phospholipids offered to L. Vannamei reared in LSW in Arizona, however, the diet contained all five supplements and it was unclear which or what combination provided the observed benefit. Shiau \& Hseih ${ }^{9}$ reported a beneficial effect of dietary K supplementation for Penaeusmonodon. ${ }^{18}$ Requirements for the culture of the Pacific white shrimp Litopenaeusvannamei, reared in low salinity waters: water modification and nutritional strategies for improving production

Similarly in study made in Alabama, a number of dietary supplementation trials were conducted with chloride salts and chelated minerals. ${ }^{66,67}$ Dietary supplementation of sodium chloride salt at levels of $1 \%$ and $2 \%$ did not increase growth or survival of shrimp reared in 4 ppt LSW. ${ }^{66}$ While chelated K supplemented at $1 \%$ of the diet was promising in reconstituted LSW (4 ppt) in the laboratory. ${ }^{66}$ Likewise supplementation of magnesium in excess of the requirement for shrimp did not provide any benefit in laboratory trials (4 ppt) using magnesium chloride (150 mg kg-1; $\left.300 \mathrm{mg} \mathrm{kg}^{-1}\right)$ or farm trials using magnesium chelates $(0.15 \%, 0.30 \%, 0.60 \%){ }^{66,68}$ So the supplementation and fertilization of the inland saline water with minerals should be studied in the concurrent application as the combined affect will have a better utilization on farm.

\section{Vitamins}

Vitamins are organic compounds that are required in a trace amount from an exogenous source, but necessary for normal growth, reproduction and health of aquatic animals. ${ }^{69}$ Role of these vitamins 
becomes more crucial when the homeostasis is deviated due to the change in environment or the nutrient utilization alteration. Since the overall energy demand increases in the inland saline water so the total requirement of vitamins pertaining to energy utilization and metabolism increases. Thirteen vitamins, including three fatsoluble vitamins (vitamin A, D and E) and ten water-soluble vitamins (thiamine, riboflavin, pyridoxine, nicotinic acid, biotin, folic acid, vitamin B12, inositol, choline and vitamin C), have been shown to be dietary essentials for fish and shrimp. ${ }^{70}$ Just for example we know, that $L$. vannamei is a strong osmoregulator, ambient salinity changes may still cause stress and lead to oxidative stress due to free radical generation. ${ }^{71}$ It has been known that the health status of aquatic organisms is closely associated with the overproduction of reactive oxygen species and antioxidants protect cell membranes against the production of free radicals. ${ }^{72}$ Dietary vitamin $\mathrm{E}$ and vitamin $\mathrm{C}$ can enhance the oxidative stability of aquatic animals, owing to their ability to scavenge free radicals, which are evidenced in several studies in L. vannamei. ${ }^{73,74}$

The dietary needs for ascorbic acid (vitamin C) while feeding live feed, the AA content in various live food has been studied. ${ }^{75}$ Application of boosting health and growth using ascorbyl palmitate (AP) and vitamin $\mathrm{C}$ enabled the transfer of elevated levels of bioactive vitamin $\mathrm{C}$ via the live food chain into $L$. vannamei larvae. The $L$. vannamei postlarvae fed $0-20 \mathrm{ppm}$ of AP had lower survival than those fed 40-100 ppm of AP following instantaneous salinity drop from seawater to 0 ppt. The highest survival was achieved when shrimp were fed with $2000 \mathrm{ppm}$ AP. An experiment was conducted to examine the effects of dietary tocopheryl acetate (vitamin E) and salinity on the muscle superoxide dismutase (SOD), catalase (CAT), glutathione peroxidase (GPX) activity and gill $\mathrm{Na}^{+} / \mathrm{K}^{+}$-ATPase activity in $L$. vannamei fed three diets containing 0,100 or $600 \mathrm{mg}$ tocopheryl acetate per kg diet, respectively, for 35 days at the salinity of 30 ppt. $^{72}$ At the end of the growth trial, shrimp were subjected to an acute salinity change ( $30 \mathrm{ppt}$ to $5,15,30$ or $50 \mathrm{ppt}$ ) for $24 \mathrm{~h}$. After exposure to 5 or $50 \mathrm{ppt}$, the SOD, CAT and GPX activities of shrimp in all dietary groups were decreased in comparison with shrimp in the 30 pptcontrol, with the exception of the increases of SOD in shrimp at 50pptand GPX in shrimp at 5 ppt. Therefore, the appropriate level of vitamin $\mathrm{E}$ in diet can enhance the ability of shrimp to resist acute changes of salinity and abnormal salinity composition of inland saline water. Overall, dietary vitamin E, as an effective antioxidant, can regulate the osmotic balance and resistance to salinity changes in shrimp and fish. Another important vitamin ascorbic acid has been found to have pronounced effect on salinity stress and water quality check. Routinely in hatcheries the vitamin c powder is applied after water exchange to reduce the stress of salinity change and handling.

Another aspect comes the dietary requirement of vitamin B complexes especially niacin, biotin and pyridoxine of $L$. vanname $i$ at the salinity of $3 \mathrm{ppt}$, which was evaluated by examining the growth responses, survival and amino-transferase activities of shrimp. ${ }^{76}$ Vitamin B6 participates as a prosthetic group of enzymes in metabolism and is particularly associated with protein and amino metabolism. ${ }^{77} \mathrm{~A}$ high protein diet can improve the growth of $L$. vannamei at low salinity, as dietary amino acids could serve as an osmotic regulator, reduce energy loss from muscles and thus promote growth. Therefore, the interaction of dietary vitamin B6 and protein on growth and gluconeogenesis and amino-transferase activities of shrimp at low salinity of becomes important. Similarly in on farm practice supplementation of the niacin, biotin and folate has potential better result in low salinity culture. Beside this the vitamins has been found to give positive result with other additives in low salinity culture like carotenoids.

\section{Targeted additives to explore}

Targeted additives for low salinity or deviated salinity adaptation is gaining high importance by farmers, several water conditioning additives like sea fresh by $\mathrm{CP}$ group Thailand are available in market. These product are targeted for the application in water and feed for improving the feed response and growth in deviated salinity regions. These product can also be targeted and tested for the use in inland saline water culture on basis of the trail. Dietary astaxanthin, a carotenoid pigment, has been suggested as an effective means to reduce stress in shrimp in ISW culture. ${ }^{78}$ Flores et al. ${ }^{79}$ reported that $80 \mathrm{mg} \mathrm{kg}^{-1}$ astaxanthin enhanced daily growth coefficient as well as hemolymph concentrations of glucose, lactate, and haemocyanin compared to the other diets tested in the 6 week study conducted in 3 ppt LSW (0,40, and $150 \mathrm{mg} \mathrm{kg}^{-1}$ astaxanthin). Increased survival of $L$. vannamei when offered dietary supplementation.

As a strong antioxidant, astaxanthin can effectively scavenge free radicals and improve antioxidant defences in aquatic animals, ${ }^{78}$ and it is more efficiently assimilated than any potential to improve the performance of L. vannamei at low salinity through adding antioxidants. The supplemented astaxanthin of $80 \mathrm{mg} \mathrm{kg}^{1}$ diet improved the growth, survival, moult frequency, haemolymph concentrations of glucose, lactate, haemocyanin and total hemocyte count of shrimp. Likewise, potential manipulations of gastrointestinal microflora in aquatic animals by application of dietary probiotics suggest that it can enhance the growth efficiency and disease or stress resistance in aquatic animals. ${ }^{80}$ Dietary supplementation of GroBiotic-a probiotic formulation hasim proved the survival of shrimp cultured at low salinity ( $2 \mathrm{ppt})$. However, the growth enhancement by brewer's yeast or GroBiotic - A was not observed in shrimp, although their inclusion could improve growth in fish when each component was supplemented at $2 \%$ or $5 \%$ in the diet. ${ }^{81}$ Many free amino can affect osmoregulation of various aquatic animals, including glycine, alanine, proline and taurine. ${ }^{82}$ Therefore, dietary supplementation of specific potential free amino acid would be a practical way to improve the performance of shrimp and fish at low salinity by maintaining shrimp osmotic balance. Among the amino acids, dietary glycine has a critical role in the osmoregulatory responses of $L$. vannamei ${ }^{83}$ and dietary glycine supplementation may improve the oxidation resistance capacity of $L$. vannamei. The survival and the $\mathrm{Na}^{+} / \mathrm{K}^{+}$-ATPase activity in shrimp haematological and hepatopancreas after $2 \mathrm{~h}$ and $3 \mathrm{~h}$ acute salinity challenge significantly increased with the increasing dietary glycine levels. The SOD activity in shrimp hepatopancrease after salinity change significantly decreased compared with that in shrimp before challenge ${ }^{83}$ In contrast, as an $\mathrm{N}$-methylated amino acid, the effects of betaine as a feed supplement was studied on the survival and growth of $L$. vannamei reared at salinities of $0.5 \mathrm{ppt}^{84-101}$

\section{Conclusion}

Aquaculture of shrimp and fish in inland saline waters has increasing awareness and huge potential. It has got considerable success in various part of world. However, a number of production problems appear to be associated with suboptimal ionic profiles of the water and the ability of aquatic animal to osmoregulate at given life stage. As nutrient intake directly and indirectly influences animals' tolerance of stress, the supplementation of selected minerals, vitamins, protein, lipids, carbohydrates and other targeted additives has lot of scope to intervene in making this culture sustainable. Overall the dietary level of these nutrients in culture in inland saline must be above the levels typically used in marine fish and shrimp feeds and studies in relation to its elevated requirement appears warranted. 


\section{Conflicts of interest}

Authors have no conflict of interest regarding this work.

\section{Acknowledgements}

Authors are extremely thankful to Dr. Gopal Krishna, Director, Central Institute of Fisheries Education, Mumbai India for providing all the facilities required.

\section{References}

1. Doupé R, Lymbery A, Sarre G, et al. The national research and development plan for commercial inland saline aquaculture: a view from afar. Natural Resource Management. 2003;6(1):31-34

2. Allan GL, Banens B, Fielder DS. Developing commercial inland saline aquaculture in Australia: Part 2. Resources inventory and assessment. NSW Fisheries Final Report Series No. 31. NSW Fisheries, Australia. 2001 .

3. Partridge GJ, Lymbery AJ. The effect of salinity on the requirement for potassium by barramundi (Latescalcarifer) in saline groundwater. Aquaculture. 2008;278(1-4):164-170.

4. Boyd E. Groundwater quality in aquaculture. Global Aquaculture seaweeds as food stock for biofuels. Delta Nuts, M delburg. Groundwater quality in aquaculture. Global Aquaculture. 2012.

5. Mourad NS, Kreydiyyeh J, Ghanawi IP, et al. Aquaculture of marine fish in inland low salinity well water: potassium is not the only limiting element. Fisheries and Aquaculture Journal. 2012;42:1-12

6. Partridge GJ, Lymbery AJ, George RJ. Finfish mariculture in inland Australia: A review of potential water sources, species, and production systems. Journal of the World Aquaculture Society. 2008;39:291-310.

7. Rayment GE, Higginson FR. Australian laboratory handbook of soil and water chemical methods. Inkata Press, Melbourne. 1992.

8. Pequeux A. Osmotic regulation in crustaceans. Journal of Crustacean Biology. 1995;15:1-60.

9. Shiau SY, Hsieh JF. Dietary potassium requirement of juvenile grass shrimp. Penaeus monodon. Fisheries Science. 2001;67(4):592-595.

10. Mantel LH, Farmer LL. Osmotic and ionic regulation. In: LH Mantel (Ed.), The Biology of Crustacea, Internal Anatomy and Physiological Regulation, Academic Press, USA. 1983;pp.54-162.

11. Jana SN, Garg SK, Patra BC. Effect of periphyton on growth performance of grey mullet, Mugil cephalus (Linn.), in inland saline groundwater ponds. Journal of Applied Ichthyology. 2004;20(2):110-117.

12. Rahman SU, Jain AK, Reddy AK, et al. Ionic manipulation of inland saline groundwater for enhancing survival and growth of Penaeus monodon (Fabricius) Aquaculture Research. 2005;36(12):1149-1156.

13. Jana SN, Garg SK, Thirunavukkarasu AR, et al. Use of additional substrate to enhance growth performance of milkfish, Chanoschanos (Forsskal) in Inland Saline Groundwater ponds . Journal of Applied Aquaculture. 2006;18:1-20.

14. Ruello N. Use of inland saline waters for aquacuIture in NSW. A preliminary (desktop) appraisal. Unpublished report to NSW Fisheries. Ruello and Associates, Henley, NSW. 1996.

15. Boeuf $G$ and Payan P. How should salinity influence fish growth? Comp Biochem Physiol C Toxicol Pharmacol. 2001;130(4):411-423.

16. Tseng YC, Hwang PP. Some insights into energy metabolism for osmoregulation in fish. Comparative Biochemistry and Physiology. 2008;148(4):419-429.

17. Wyban JA, Sweeney JN. Intensive shrimp production technology. High Health Aquaculture Inc., Hawaii. 1991;pp.158
18. Roy L and Davis A. Requirements for the culture of the Pacific white shrimp Litopenaeus vannamei, reared in low salinity waters: water modification and nutritional strategies for improving production. In: Cruz-Suárez \& LE Ricque-Marie (Eds.), Avances en NutriciónAcuícola $\mathrm{X}$ - Memorias del DécimoSimposioInternacional de NutriciónAcuícola, 8-10 de Noviembre, San Nicolás de los Garza, Universidad Autónoma de Nuevo León, Monterrey, México. 2010;pp.61-78.

19. Genovese G, Luquet C, Paz D, et al. The morphometric changes in the gills of the estuarine crab Chasmagnathus granulatus under hyper- and hyporegulation conditions are not caused by proliferation of specialized cells. Anat. 2000;197:239-246.

20. Alvarez A, Racotta I, Arjona O, et al. Salinity stress test as a predictor of survival during growout in Pacific white shrimp Litopenaeusvannamei. Aquaculture. 2004;237(1-4):237-249.

21. Palacios E, Bonilla A, Pérez A, et al. Influence of highly unsaturated fatty acids on the responses of white shrimp (Litopenaeus vannamei) postlarvae to low salinity. Journal of Experimental Marine Biology and Ecology. 2004;299(2):201-215.

22. Loeza F, Hurtado MA, Ramírez JL, et al. Effect of HUFA on osmoregulatory capacity in shrimp (Litopenaeusvannamei) postlarvae. $6^{\text {th }}$ International Crustacean Congress, Glasgow, UK. 2005;pp.167.

23. Rees JF, Cure K, Piyatiratitivorakul S, et al. Highly unsaturated fatty acid requirements of Penaeus monodon postlarvae: an experimental approach based on Artemia Aquaculture. 1994;122:193-207.

24. Gao WH, Tan BP, Mai KS, et al. Profiling of differentially expressed genes in hepatopancreas of white shrimp (Litopenaeusvannamei) exposed to long-term low salinity stress. Aquaculture. 2012;364 365:186-191.

25. Li EC, Chen LQ, Zeng C, et al. Comparison of digestive and antioxidant enzymes activities, haemolymph oxyhemocyanin contents and hepatopancreas histology of white shrimp, Litopenaeusvannamei, at various salinities. Aquaculture. 2008a ;274(1):80-86.

26. FAO. Manejosanitario y mantenimiento de la bioseguridad de los laboratorios de postlarvas de camarónblanco (Penaeusvannamei) en América Latina, FAO DocumentoTécnico de Pesca. 2004pp.1-79.

27. Mc Kenney C Jr, Celestial, DM. Interactions among salinity, temperature and age on growth of the estuarine mysidMysidopsisbahia reared in the laboratory through a complete life cycle. Journal of Crustacean Biology. 1995;15(1):169-178.

28. Pham D, Charmantier G, Wabete N, et al. Salinity tolerance, ontogeny of osmoregulation and zootechnical improvement in the larval rearing of the Caledonian Blue Shrimp, Litopenaeus stylirostris (Decapoda, Penaeidae). Aquaculture. 2012b;362-363:10-17.

29. Al-Amoudi MM. the effect of high salt diet on the direct transfer of Oreochromis mossambicus, spilurus and O.aureus/O. niloticus hybrids to sea water. Aquaculture. 1987;64(4):333-338.

30. Cnaani A, Barki A, Slossman T, et al. Dietary salt supplementation increases the growth rate in freshwater cultured tilapia hybrids. Aquaculture Research. 2010;41(10):1545-1548.

31. Palacios E, Pérez-Rostro CI, Ramírez JL, et al. Reproductive exhaustion in shrimp (Penaeus vannamei) reflected in larval biochemical composition, survival, and growth. Aquaculture. 1999;171(3-4):309321

32. Chausson F and Regnault M. Teneur en glycogène des branchiespostérieures de Carcinusmaenas: comparaison entre branchiesantérieuresetposté Cahiers de Biologie Marine. 1995;36:291297.

33. Wang X, Ma M, Dong S, et al. Effects of salinity and dietary carbohydrate levels on growth and energy budget of juvenile Litopenaeusvannamei. Journal of Shellfish Research. 2004;23:231-236. 
34. Marangos $\mathrm{C}$, Brogren $\mathrm{CH}$, Alliot $\mathrm{E}$, et al. The influence of water salinity on the free amino acid concentration in muscle and hepatopancreas of adult shrimps, Penaeusjaponicus. Biochem. Syst. Ecol. 1989;17:589594.

35. Charmantier G. L'osmoregulation chezles crevettespenaeidae. Oceanis. 1987;13(2):179-196.

36. Holliday CW. Salinity-induced changes in gill Na, K-ATPase activity in the mud fiddler crab, Uca pugnax. Search Results. Journal of Experimental Zoology. 1985;233(2):199-208.

37. Palacios E, Bonilla A, Luna D, et al. Survival to a salinity stress test and osmoregulatory responses of starved and fed Litopenaeus vannamei Aquaculture. 2004a;234:497-511.

38. Luvizotto-Santos R, Lee Jt, Branco Zp, et al. Lipids as energy source during salinity acclimation in the eurohaline crab Chasmagnathus granulate Dana, 1851 (Crustacea-Grapsidae). J Exp Zool A Comp Exp Biol. 2003;295(2):200-205.

39. Kinsey ST, Buda E, Nordeen J. Scaling of gill metabolic potential as a function of salinity in the eurohaline crab, Callinectessapidus. Physiological and Biochemical Zoology. 2003;76(1):105-114.

40. Palacios E, Bonilla A, Pérez A, et al. Influence of highly unsaturated fatty acids on the responses of white shrimp Litopenaeus vannameipostlarvae to low salinity. Journal of Experimental Marine Biology and Ecology. $2004 b ; 299(2): 201-215$.

41. Liu D, He J, Liu Y, et al. Effects of dietary protein levels on growth performance and immune condition of pacific white shrimp Litopenaeus vannamei juveniles at very low salinity. Acta Scientiarum Naturalium Universitatis Sunyatseni. 2005;44:217-223.

42. Li EC, Chen LQ, Zeng C, et al. Effects of dietary protein levels on growth, survival, body composition and hepatopancreas histological structure of the white shrimp, Litopenaeus vannamei, at different ambient salinities. Journal of Fisheries of China. 2008c;32:425-434.

43. Roy LA, Davis DA, Saoud IP, et al. Branchial carbonic anhydrase activity and ninhydrin positive substances in the Pacific white shrimp, Litopenaeus vannamei, acclimated to low and high salinities. Comp Biochem Physiol A Mol Integr Physiol. 2007;147(2):404-411.

44. Morris RJ, Lockwood APM, Dawson ME. An effect of acclimation salinity on the fatty acid composition of the gill phospholipids and water flux of the amphipod crustacean Gammarusduebeni. Comparative Biochemistry and Physiology. 1982;72(3):497-503.

45. Chapelle S, Dandrifosse G, Zwingelstein G. Metabolism of phospholipids of anterior or posterior gills of the crab Eriocheir sinenesis EDW, during the adaptation of this animal to media of various salinities. International Journal of Biochemistry. 1976;7(6-7):343-351.

46. Hazel JR, Williams EE. The role of alterations in membrane lipid composition in enabling physiological adaptation of organisms to their physical environment. Progress in Lipid Research. 199029(3):167-227.

47. Zwingelstein G, Bodennec J, Brichon G, et al. Formation of phospholipid nitrogenous bases in euryhaline fish and crustaceans. I. Effects of salinity and temperature on synthesis of phosphatidylserine and its decarboxylation. Comparative Biochemistry and Physiology Part B: Biochemistry and Molecular Biology. 1998;120(3):467-473.

48. Chapelle S, Zwingelstein G. Phospholipid composition and metabolism of crustacean gills as related to changes in environmental salinities: relationship between $\mathrm{Na}^{+} \mathrm{K}^{+}$ATPase activity and phospholipids. Comparative and Biochemical Physiology. 1984;78(2):363-372.

49. Haines TH. Water transport across biological membranes. FEBS Lett. 1994;346(1):115-122.

50. Paibulkichakul C, Piyatiratitivorakul S, Kittakoop P, et al. Optimal dietary levels of lecithin and cholesterol for black tiger prawn Penaeus monodon larvae and postlarvae. Aquaculture. 1998;167(3-4):273-281.
51. Teshima S. Phospholipids and Sterols. In: Crustacean Nutrition (ed. by L.D. D’Abramo, D.E. Conklin \& D.M. Akiyama), pp. 85-107. World Aquaculture Society. Louisiana State University, Baton Rouge, LA. 1986.

52. Teshima S, Ishikawa M, Koshio S, et al. Assessment of cholesterol requirements in the prawn, Penaeusjaponicus. Aquaculture Nutrition. 19973(4):247-253.

53. Teshima S, Kanazawa A, Kakuta Y. Role of dietary phospholipids in the transport of cholesterol in prawn. Bulletin of the Japanese Society of Scientific Fisheries. 1986;25:714-723.

54. Gong H, Jiang DH, Lightner DV, et al. A dietary modification approach to improve the osmoregulatory capacity of Litopenaeus vannamei cultured in the Arizona desert. Aquaculture Nutrition. 2004;10(4):227-236.

55. Palacios E, Bonilla A, Luna D, et al. Survival, Na+/K+-ATPase and lipid responses to salinity challenge in fed and starved white pacific shrimp (Litopenaeusvannamei) postlarvae. Aquaculture. 2004;234(14):497-511.

56. Wang X, Li E, Qin JG, et al. Growth, body composition, and ammonia tolerance of juvenile white shrimp Litopenaeus vannamei fed diets containing different carbohydrate levels at low salinity. Journal of Shellfish Research. 2014a ;33(2):511-517.

57. Roy LA, Davis DA, Saoud IP, et al. Effects of varying levels of aqueous potassium and magnesium on survival, growth, and respiration of the Pacific white shrimp, Litopenaeus vannamei, reared in low salinity waters. Aquaculture. $2007 \mathrm{~b} ; 262: 461-469$

58. Roy LA, Davis DA, Whitis GN. Pond-to-pond variability in post-larval shrimp, Litopenaeus vannamei, survival and growth in inland low salinity waters of west Alabama. Aquaculture Research. 2009;40(16):1823-1829.

59. Boyd CA, Boyd CE \& Rouse DB. Potassium adsorption by bottom soils in ponds for inland culture of marine shrimp in Alabama. Journal of the World Aquaculture Society. 2007a;38(1):85-91.

60. Zhu C, Dong S, Wang F, et al. Effects of $\mathrm{Na} / \mathrm{K}$ ratio in seawater on growth and energy budget of juvenile Litopenaeus vannamei. Aquaculture. 2004234(1-4):485-496.

61. Zhu C, Dong S, Wang F. The interaction of salinity and $\mathrm{Na} / \mathrm{K}$ ratio in seawater on growth, nutrient retention and food conversion of juvenile Litopenaeus vannamei. Journal of Shellfish Research. 2006;25(1):107-112.

62. Charmantier G and Soyez C. Effect of molt stage and hypoxia on osmoregulatory capacity in the penaeid shrimp Penaeusvannamei. Journal of Experimental Marine Biology and Ecology. 1994;178:233246

63. Rasmussen AD, Andersen O. Apparent water permeability as a physiological parameter in crustaceans. J Exp Biol. 1996;199(12):25552564 .

64. Davis DA, Lawrence AL. Minerals. In: D’Abramo LR, Conklin DE, Akiyama DM (Eds.), Crustacean Nutrition, Vol. 6. 1997;pp.150-163. World Aquaculture Society, Baton Rouge, Louisiana.

65. Gatlin DM III, Mac Kenzie DS, Craig SR, et al. Effects of dietary sodium chloride on red drum juveniles in waters of various salinities. Progressive Fish Culturist. 1992;54:220-227.

66. Roy LA, Davis DA, Saoud IP, et. Supplementation of potassium, magnesium, and sodium chloride in practical diets for the Pacific white shrimp, Litopenaeus vannamei, reared in low salinity waters. Aquaculture Nutrition. 2007c;13(2):104-113.

67. Saoud IP, Roy LA, Davis DA. Chelated potassium and arginine supplementation in diets of Pacific white shrimp reared in low-salinity waters of west Alabama. North American Journal of Aquaculture. 2007;69(3):265-270. 
68. Roy LA, Davis DA, Nguyen TN, et al. Supplementation of chelated magnesium to diets for Litopenaeus vannamei reared in low salinity waters of west Alabama. Journal of the World Aquaculture Society. 2009;40(2):248-254.

69. NRC. Nutrient Requirements of Fish and Shrimp. The National Academies Press, Washington, DC, USA. 2011.

70. Lim C, Akiyama DM. Nutrient requirements of Penaeid shrimp. In: Lim C, Sessa DJ (eds). Nutrition and Utilization Technology in Aquaculture. 1995;pp.60-73. The American Oil Chemists Society, Champaign, IL.

71. Siers. Oxidative Stress. Academic Press, New York City, NY. 1985;pp.17.

72. Liu Y, Wang WN, Wang AL, et al. Effects of dietary vitamin E supplementation on antioxidant enzyme activities in Litopenaeusvannamei (Boone, 1931) exposed to acute salinity changes. Aquaculture. 2007;265:351-358.

73. Evstigneeva RP, Vokkov IM, Chudinova VV. Vitamin E as a universal antioxidant and stabilizer of biological membranes. Membrane \& Cell Biology. 1998;12:151-172.

74. Merchie G, Kontara E, Lavens P, et al. Effect of vitamin C and astaxanthin on stress and disease resistance of postlarval tiger shrimp, Penaeusmonodon (Fabricius). Aquaculture Research. 1998;29:579-585.

75. Merchie G, Lavens P, Sorgeloos P. Effects of dietary vitamin C on fish and crustacean larvae. Special Publication of European Aquaculture Society. 1995;24:229.

76. Li EC, Yu N, Chen LQ, et al. Dietary vitamin B6 requirement of the Pacific white shrimp, Litopenaeusvannamei, at low salinity. Journal of the World Aquaculture Society. $2010 \mathrm{~b} ; 41: 756-763$.

77. Shiau SY, Wu MH. Dietary vitamin B6 requirement of grass shrimp Penaeusmonodon. Aquaculture. 2003;225:397-404.

78. Chien $\mathrm{YH}$, Pan $\mathrm{CH}$, Hunger B. The resistance to physical stresses by Penaeusmonodonjuveniles fed diets supplemented with astaxanthin. Aquaculture. 2003;216,177-191.

79. Flores M, Diaz F, Medina R, et al. Physiological, metabolic and haematological responses in white shrimp Litopenaeusvannamei (Boone) juveniles fed diets supplemented with astaxanthin acclimated to lowsalinity water. Aquaculture Research. 2007;38:740-747.

80. Burr G, Gatlin D, Ricke S. Microbial ecology of the gastrointestinal tract of fish and the potential application of prebiotics and probiotics in finfish aquaculture. Journal of the World Aquaculture Society. 2005;36:425436.

81. Li P, Wang X, Murthy S, et al. Effect of dietary supplementation of brewer's yeast and GroBiotic-A on growth, immune responses, and lowsalinity tolerance of pacific white shrimp Litopenaeusvannamei cultured in recirculating systems. Journal of Applied Aquaculture. 2009;21:110 119.

82. Deaton LE. Hyperosmotic volume regulation in the gills of the ribbed mussel, Geukensiademissa: rapid accumulation of betaine and alanine. Journal of Experimental Marine Biology and Ecology. 2001260:185197.

83. Xie SW, Tian LX, Jin Y, et al. Effect of glycine supplementation on growth performance, body composition and salinity stress of juvenile Pacific white shrimp, Litopenaeusvannamei fed low fishmeal diet. Aquaculture. 2014;418:159-164.

84. Charmantier G. Ontogeny of osmoregulation in crustaceans: a review. Invertebrate Reproduction and Development. 1998;33:177-190.

85. Charmantier G, Charmantier-Daures M, Aiken DE. Metamorphosis in the lobster Homarus (Decapoda): a review. Journal of Crustacean Biology. 1991;11:481-495.
86. Charmantier G, Charmantier-Daures MDT. Osmotic and ionic regulation in aquatic arthropods. In: Evans DH (Ed.), Osmotic and ionic regulation. Cells and animals. CRC Press, UK. 2009;pp.165-230.

87. Charmantier G, Charmantier-Daures M, Bouricha N, et al. Ontogeny of Osmoregulation and Salinity Tolerance in Two Decapod Crustaceans: Homarus americanus and Penaeus Japonicus. The Biological Bulletin. 1988; 175:102-110

88. Cheng KM, Hu CQ, Liu YN, et al. Dietary magnesium requirement and physiological responses of marine shrimp Litopenaeus vannamei reared in low salinity water. Aquaculture Nutrition. 200511(5):385-393.

89. González-Félix ML, Perez-Velazquez M, Quintero-Alvarez JM, et al. Effect of various dietary levels of docosahexaenoic and arachidonic acids and different $n-3 /-6$ ratios on biological performance of Pacific white shrimp, Litopenaeus vannamei, raised in low salinity water. Journal of the World Aquaculture. Society. 2009;40(2):194- 206.

90. Huai MY, Tian LX, Liu YJ, et al. Quantitative dietary threonine requirement of juvenile Pacific white shrimp, Litopenaeus vannamei (Boone) reared in low salinity water. Aquaculture Research. 200940(8):904-914

91. Jain AK, Kumar G, Mukherjee SC. Survival and growth of early juveniles of barramundi, Latescalcarifer (Bloch, 1790) in inland saline groundwater. Journal of Biological Research . 2006;5:93-97.

92. Li EC, Chen LQ, Zeng C, et al. Growth, body composition, respiration and ambient ammonia nitrogen tolerance of the juvenile white shrimp, Litopenaeus vannamei, at different salinities. Aquaculture. 2007;265(1-4):385-390.

93. Li E, Xiong Z, Chen L, et al. Acute toxicity of boron to juvenile white shrimp, Litopenaeus vannamei, at two salinities. Aquaculture. 2008b 278(1-4):175-178.

94. Li P, Wang X, Murthy S, et al. Effect of dietary supplementation of brewer's yeast and GroBiotic $(\mathbb{R}-\mathrm{A}$ on growth, immune responses, and low-salinity tolerance of Pacific white shrimp Litopenaeus vannamei cultured in recirculating systems. Journal of Applied Aquaculture. 2009;21(9):110-119.

95. Liu FJ, Liu YJ, Tian LX, et al. Quantitative dietary leucine requirement of juvenile Pacific white shrimp, Litopenaeus vannamei (Boone) reared in low salinity water. Aquaculture Nutrition. 201420(3):332-340.

96. Roy LA, Davis DA, Saoud IP. Effects of lecithin and cholesterol supplementation to practical diets for Litopenaeus vannamei reared in low salinity waters. Aquaculture. 2006257(1-4):446-452.

97. Roy LA, Davis DA, Saoud IP, et al. Effects of varying levels of aqueous potassium and magnesium on survival, growth, and respiration of the Pacific white shrimp, Litopenaeus vannamei, reared in low salinity waters. Aquaculture. 2007;262(2-4):461-469.

98. Roy LA, Bordinhon A, Sookying D, et al. Demonstration of alternative feeds for Litopenaeus vannamei reared in low salinity waters of west Alabama. Aquaculture Research. 2009;40(4):496-503.

99. Saoud IP, Davis DA. Effects of betaine supplementation to feeds of Pacific white shrimp Litopenaeus vannamei reared at extreme salinities. North American Journal of Aquaculture. 2005;67(4):351-353.

100. Xia M, Huang X, Li M, et al. Dietary biotin requirement of juvenile Pacific white shrimp (Litopenaeus vannamei). Journal of Animal Nutrition. 2014a 26(6):1513-1520.

101. Xia MH, Huang XL, Wang HL, et al. Dietary niacin levels in practical diets for Litopenaeus vannamei to support maximum growth. Aquaculture Nutrition. 2014b;21(6):853-860. 